\title{
Biological and Cellular Functions of the Microdomain-Associated FWL/CNR Protein Family in Plants
}

\author{
Sandra Thibivilliers ${ }^{1}$, Andrew Farmer ${ }^{2}$ and Marc Libault ${ }^{1, *}$ \\ 1 Department of Agronomy and Horticulture, Center for Plant Science Innovation, \\ University of Nebraska-Lincoln, Beadle Center, Lincoln, NE 68503, USA; sthibi@unl.edu \\ 2 National Center for Genome Resources, Santa Fe, NM 87505, USA; adf@ncgr.org \\ * Correspondence: marc.libault@unl.edu; Tel.: +1-402-472-4530
}

Received: 29 February 2020; Accepted: 18 March 2020; Published: 19 March 2020 updates

\begin{abstract}
Membrane microdomains/nanodomains are sub-compartments of the plasma membrane enriched in sphingolipids and characterized by their unique protein composition. They play important roles in regulating plant development and plant-microbe interactions including mutualistic symbiotic interactions. Several protein families are associated with the microdomain fraction of biological membranes such as flotillins, prohibitins, and remorins. More recently, GmFWL1, a FWL/CNR protein exclusively expressed in the soybean nodule, was functionally characterized as a new microdomain-associated protein. Interestingly, GmFWL1 is homologous to the tomato FW2-2 protein, a major regulator of tomato fruit development. In this review, we summarize the knowledge gained about the biological, cellular, and physiological functions of members of the FWL/CNR family across various plant species. The role of the FWL/CNR proteins is also discussed within the scope of their evolution and transcriptional regulation.
\end{abstract}

Keywords: FWL/CND; microdomains; plasma membrane; legume nodulation; plant development

\section{Role of Plasma Membrane Micro/Nanodomain in Plant Biology}

Eukaryotic biological membranes consist of bilayers of lipids embedded with proteins. The lipid and protein compositions of biological membranes strongly influence their functions [1]. For instance, membrane micro/nanodomains (referred to in this review as microdomains) are sub-compartments of biological membranes well-characterized for their unique lipid and protein composition (i.e., microdomains are enriched in sterols and sphingolipids, and in specific classes of proteins such as stomatin, prohibitin, flotillin, and HflK/C proteins (also known as SPFH proteins)) [2-4]. Microdomains are not static lipid/protein islands in the plasma membrane; their dynamic reallocation in the plasma membrane plays a critical role in controlling cell morphology and physiology [5].

For instance, the polar accumulation of auxin in the root is under the control of auxin transporters including the PIN1, 2, and 3 proteins [6,7]. The polar localization of PIN1 and 3 is regulated by the sterol methyltransferase 1 protein [8], while the polar accumulation of the PIN2 transporter in the plasma membrane depends on sterol-enriched components $[9,10]$. Microdomains play a critical role in plant [11] and cell developments (e.g., polar elongation of specialized cells such as the tip growth of the root hair cells and pollen tubes [12-14]). They also control intercellular communications: a specific population of microdomains such as those enriched in the cell-signaling regulator tetraspanin are closely associated with plasmodesmata [15-17]. Microdomains control plant response to microbial inoculations including fungal and viral infections [18-24]. In the legume model Medicago truncatula, the subcellular localization of the microdomain-associated protein FLOTILLIN2 (FLOT2) depends on the 
recognition of the symbiotic bacteria Sinorhizobium meliloti $[25,26]$. More specifically, upon microbial inoculation or application of the bacterial signaling molecule named Nod factor, FLOT2 accumulates at the tip of the Medicago root hair cell. This accumulation plays a critical role in promoting the infection of the plant root hair cell by symbiotic bacteria $[25,26]$. Flotillin-like proteins also play a role in vesicle trafficking during arbuscular mycorrhization, a symbiosis between plants and mycorrhizal fungi [27]. In M. truncatula, the SYMREM1 remorin regulates the infection of the root by S. meliloti as well as nodule development [28]. Recently, a functional analysis revealed that the medicago FLOT4 and SYMREM1 proteins interact with the receptor LYK3 to promote root hair cell infection by S. meliloti [29]. In soybean, two remorins, GmREM1.1 and GmREM2.1, have distinctive roles during the nodulation process: GmREM1.1 is transiently expressed in nodule primordia while GmREM1.2 is specifically expressed in the nodule during its entire development [30]. RNAi-mediated silencing also revealed that GmREM1.2 controls nodule formation [30]. Similarly to M. truncatula FLOT2, another soybean protein, GmFWL1 (FW2.2-LIKE 1), is also translocated at the tip of the soybean root hair cells in response to the inoculation with Bradyrhizobium diazoefficiens, the soybean symbiotic nitrogen-fixing bacterium inoculation [31]. The punctuate subcellular localization of GmFWL1 in the plant plasma membrane and its interaction with many well-characterized microdomain-associated proteins including SPFH proteins support that GmFWL1 is associated with the microdomain fraction of the soybean plasma membrane [31].

\section{Phylogeny of the $F W L / C N R$ Gene Family in Plants}

GmFWL1 belongs to the FWL/CNR gene family. Alpert et al. (1995) reported the biological function of the first member of the FWL/CNR family through a genetic analysis of the tomato fw2.2 (fruit weight 2.2) quantitative trait locus (QTL) [32]. This gene acts as a major negative regulator of tomato fruit size compared to other tomato fruit weight QTLs (i.e., up to 30\% of the tomato fruit weight [33-35]). The FW2.2 gene encodes a small protein (22 kDa) enriched in cysteine residues and characterized by one transmembrane domain [31,36-38]. The functional characterization of the protein suggests that FW2.2 acts as a negative regulator of cell division supporting the repressive role of FW2.2 in controlling tomato fruit size [34,39]. A closer analysis of the temporal transcriptional activity of FWL2.2 suggests that the timing and the level of expression of FWL2.2 during fruit development tomato contributes to regulate tomato fruit size [40]. In addition to its temporal regulation, the spatial transcriptional activity of FW2.2 is restricted to the fruit epidermal and sub-epidermal cells. The division rate of these two cell types is critical in regulating tomato fruit size [41].

Taking advantage of the most recent releases of plant genomic sequences and their enhanced annotation [42], we looked for the FWL/CNR members across 13 different plant species (i.e., Arabidopsis thaliana [43], Glycine max [44], Lotus japonicus [45], Medicago truncatula [46], Phaseolus vulgaris [47], Vitis vinifera [48], Solanum lycopersicum [49], Populus trichocarpa [50], Ricinus communis [51], Oryza sativa [52,53], Zea mays [54], Brachypodium distachyon [55], and Physcomitrella patens [56]). These selected species cover different phyla of the plant kingdom including moss, monocotyledons, and dicotyledons. We identified 134 members in the FWL/CNR family (i.e., BlastP, e-value $\leq 10 \mathrm{e}-20$ and score $\geq 100$; Table S1). Among them, several members were characterized for their role in plant and fruit development across several mono- and di-cotyledons (Figure 1, red boxes). Notably, the maize gene cell number regulator1 (CNR1; ZmFWL6) negatively controls the overall plant size [57,58]. The biological function of other FWL/CNR genes as negative regulators of cell division and fruit development has also been described in Oryza sativa (OsFWL3; [38]), husk tomato (Physalis floridana CNR1; [37]), sweet cherry (Prunus avium CNR12 and CNR20; [59]), and in avocado (Persea americana; [60]). 


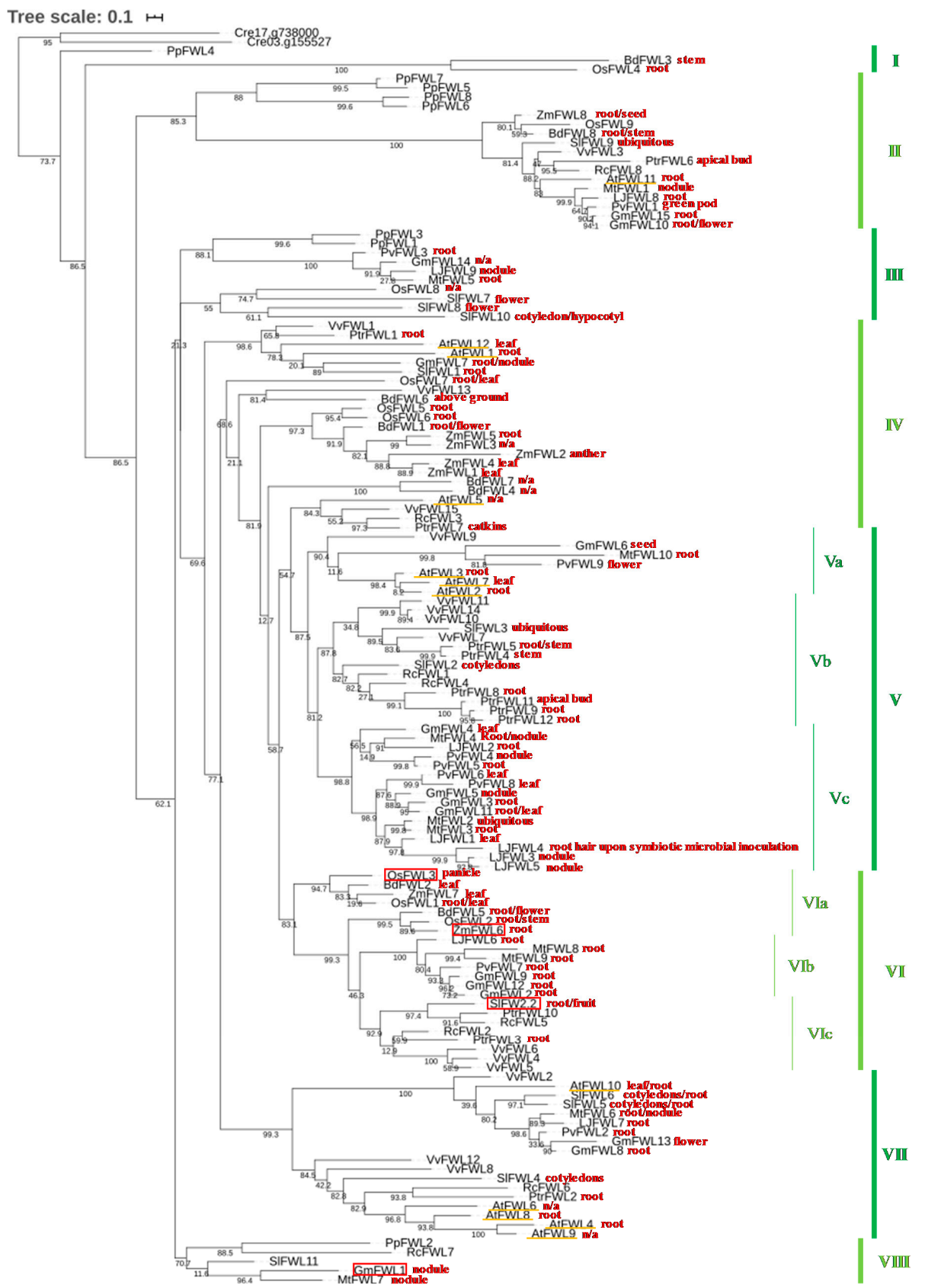

Figure 1. Phylogenetic tree of the FWL/CNR family. Members of the FWL/CNR family were identified with BlastP analysis against the genomic sequence of 13 different plant species. The $103 \mathrm{FWL} / \mathrm{CNR}$ protein sequences reported in Libault et al. (2010) [36] were used as queries in the Phytozome database (https://phytozome.jgi.doe.gov/; e-value $\leq 10 \mathrm{e}-20$ and score $\geq 100$ ). Alignment and phylogenetic reconstructions were performed using the function "build" of ETE3 v3.1.1 [61] as implemented on GenomeNet (https://www.genome.jp/tools/ete/). The multiple sequence alignment was performed using the CLUSTAL W Multiple Sequence Alignments Program with default parameters [62]. The tree was constructed using fasttree with slow NNI (Nearest Neighbor Interchange) and MLACC (maximum likelihood accuracy) $=3$ (to make the maximum-likelihood NNIs more at nodes exhaustive) [63]. Values are SH-like local support. Two Chlamydomonas reinhardtii proteins (Cre17.g738000 and Cre03.g155527) were used to root the tree. The tree representation was generated using https://itol.embl.de/tree/. This tree was divided into eight major clades (I to VIII). Among them, Clades V and VI were divided into three distinctive subclades. Upon mining transcriptome atlases, we highlighted in red characters the tissue/organ where each FWL/CNR gene was the most expressed. 
To enhance our understanding of the evolution of the biological functions of the 134 members of the FWL/CNR family, we analyzed their phylogenetic relationships according to their amino acid sequences. These genes are distributed in eight major clades. Clade II is composed of FWL/CNR genes from all 13 species considered in this analysis, but the four P. patens FWL/CNR genes were clustered separately from the angiosperm genes. This result suggests that a FWL/CNR common ancestor existed before the speciation between angiosperms and mosses.

Interestingly, Clades V and VII are strictly composed of dicotyledon FWL/CNR genes. Upon dividing Clade $\mathrm{V}$ into three subclades (i.e., Subclades $\mathrm{Va}, \mathrm{b}$, and c), we noticed that Clades $\mathrm{Vb}$ and $\mathrm{Vc}$ were exclusively composed of non-legume and legume FWL/CNR genes (i.e., G. max, M. truncatula, P. vulgaris, and L. japonicus), respectively. Similarly, Clade VI can be divided into three different subclades: VIa, b, and c, which are exclusively composed of monocotyledonous genes, legume genes, and non-legume dicotyledonous FWL/CNR genes, respectively. These observations suggest that subsets of FWL/CNR genes evolved to likely gain unique biological functions in monocotyledons, and in legume and non-legume dicotyledons. Exploring the role of the genes in these different subclades (i.e., between $\mathrm{Vb}$ and c, and between $\mathrm{VIa}, \mathrm{b}$, and c) could provide interesting information regarding the evolution of their biological functions. OsFWL3, ZmCNR1 (ZmFWL6), and SIFW2.2, three genes of Clade VI, act as major regulators of plant and organ development (see above). GmFWL1, a regulator of soybean nodule development and bacterial infection, belongs to Clade VIII. Interestingly, MtFWL7 is evolutionary closely related to GmFWL1, suggesting that this $M$. truncatula gene might be the functional ortholog of GmFWL1. To date, there is no report of the function of MtFWL7 during M. truncatula nodulation; this may be a consequence of functional redundancies existing between members of the M. truncatula FWL/CNR gene family expressed in nodules (see below; Figure 1)

\section{Transcriptional Regulation of the FWL/CNR Genes}

The biological function of the GmFWL1 protein during soybean nodulation [36] depends on its interaction with many well-characterized microdomain-associated proteins including remorins, flotillins, and prohibitins [31]. Among the GmFWL1 protein partners, several are encoded by nodule or root-specific genes, suggesting a unique protein composition of the soybean nodule microdomain [31]. We assume that the differential transcriptional regulation of the genes encoding microdomain-associated proteins between cell, tissues, and organs influences the protein composition of microdomains and their biological activities. As a consequence, among other regulatory mechanisms, there is a need to better understand the transcriptional pattern of microdomain-associated genes and their co-expression.

Taking advantage of the release of various plant transcriptome atlases accessible via Phytozome, the Maize eFP Browser (http://bar.utoronto.ca/efp_maize/cgi-bin/efpWeb.cgi), the Lotus Base [64], the Tomato Functional Genomics Database (http://ted.bti.cornell.edu/cgi-bin/TFGD/digital/search.cgi?ID= D006), and targeted transcriptional studies (i.e., OsFWL genes [38]), we analyzed the transcriptional pattern of members of the FWL/CNR family. Overall, a large number of the FWL/CNR genes were mostly highly expressed in the root system of the plants. More rarely, these genes were significantly expressed in the canopy of the plants (Figure 1). Taking into consideration that microdomains are important regulators of the interactions between plant cells and microbes [23], the plant FWL/CNR genes preferentially expressed in the root system might play critical roles in controlling the interaction with soil microbes. Among them, a subset of the legume FWL/CNR genes, those preferentially expressed in the nodules (i.e., GmFWL1, 3, 5, and 7, MtFWL1, 4, 6, and 7, LjFWL3, 4, and 9, and PvFWL4), are likely specialized in regulating the interaction and infection of the legume root system by nitrogen-fixing rhizobia. Notably, the LjFWL4 gene is preferentially expressed in the root hair cells upon inoculation with symbiotic microorganisms. In soybean, GmFWL1 is also highly expressed in root hair cells during the early stages of the nodulation process [36]. However, contrary to LjFWL4, GmFWL1 is also expressed later during nodule development, suggesting that in L. japonicus, different FWL genes regulate the early and late stages of the nodulation process. Conversely, in soybean, GmFWL1 integrates both functions to promote the root hair cell infection by rhizobia and the establishment of 
the symbiosis between the plant nodule cells and the bacteria [31,36]. Looking at the phylogenetic distribution of these legume nodule-specific genes, they belong to six different clades (e.g., Clades II, III, IV, V, VII, and VIII). Hence, the nodule-specific legume FWL/CNR genes independently gained their unique transcriptional patterns and biological function.

In Clade VI, SIFW2.2, ZmFWL3/CNR, and OsFWL3 were functionally characterized by their role during fruit and seed development in tomato, maize, and rice, respectively $[32,34,38,57,58]$, suggesting that other FWL/CNR members of this clade could also contribute to the fitness and development of other important crop species. By mining the transcriptome atlases, we noticed that many of the members of this clade were expressed in the plant root system (e.g., PvFWL7, GmFWL9, and 12, PtrFWL3, MtFWL8, and 9). Their putative role in root development should be further investigated.

The protein composition of the microdomains could fluctuate between organs, tissues, and even cells based on the unique transcriptional activity of the genes encoding them (e.g., GmFWL1 protein partners are encoded by nodule and root-specific genes [31]). A more targeted analysis of the transcriptional activity of plant genes encoding microdomain-associated proteins would help to estimate the complexity and diversity of populations of microdomains in and between cell types, according to their protein composition. This statement is supported by microscopic studies conducted on plant plasma membranes [65]. The recent release of Arabidopsis root transcriptomes at a single-cell resolution now allows for a deeper exploration of gene expression and co-expression [66-70]. As a first attempt, we mined one of these Arabidopsis root single-cell transcriptomic datasets [68] to quantify the level of transcriptional activity of the twelve members of the AtFWL family. Consistent with previous bulk transcriptomic datasets showing that AtFWL2, 3, 10, and 11 are preferentially expressed in the root system, we found these four genes ubiquitously expressed across many root cell types (Figure 2), but with different levels of activity (i.e., AtFWL3 is more expressed than its three other homologs). AtFWL1, 4, and 8 expression is limited to a smaller number of root cell-types (Figure 2). For instance, AtFWL1 expression is strongly restricted to trichoblasts, atrichoblasts, and stele cells. Conversely, AtFWL5, 6, 7, 9, and 12 were found to be weakly expressed and only in a few cell types (Figure 2). AtFWL6 is exclusively expressed in trichoblasts (i.e., its transcript was detected in three out of the four sub-populations of trichoblasts; Figure 2) while AtFWL7 is expressed in one sub-population of atrichoblasts and in the root tip cells. The expressions of AtFWL5 and 9 were not detected in root cells, suggesting that these two genes do not have a function in Arabidopsis root microdomains. Similar analysis should be conducted for other families of genes encoding microdomain-associated proteins such as those encoding remorin, flotillin, and prohibitins. The integration of the transcriptional patterns of microdomain-associated genes at the single-cell level would help to estimate the complexity of microdomain population between cell-types.

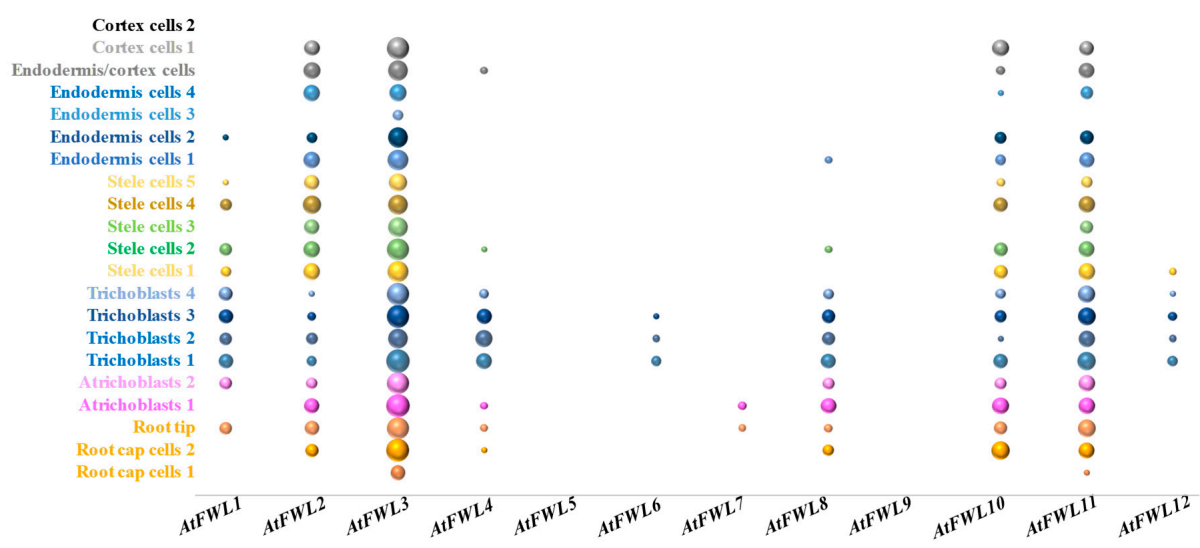

Figure 2. Expression level of the 12 Arabidopsis thaliana FWL/CNR genes in various root cell types. Each dot represents the log10-transformed expression levels of each AtFWL/CNR genes across 21 different cell cluster/cell type. Each cell cluster/cell type is represented by a different color. Root single-cell expression datasets were mined from Ryu et al., 2019 [65]. 


\section{Regulation of the Subcellular Localization of FWL/CNR Proteins}

The sub-membrane localization of microdomain-associated proteins is influenced by external and internal stimuli. For example, during the nodulation process, MtFLOT2 and GmFWL1 are both characterized by their punctuate plasma membrane localization in the root hair cells of mock-inoculated plants. However, upon rhizobia inoculation, both proteins accumulate at the tip of the root hair cell $[26,31]$. This accumulation is critical to promote the infection of the root hair cells by the symbiotic bacteria. These observations clearly highlight the influence of microbes in reshaping membrane biology in order to promote plant cell infection by rhizobia.

Plant hormones also play an important role in controlling the translocation of microdomains in specific regions of the plasma membrane. Treatment of transgenic soybean roots clearly revealed that GmFWL1 and GmFLOT2 are both translocated at the tip of the root hair cells in response to auxin and salicylic acid [71], hormones regulating nodulation and plant-microbe interactions [72-76]. Conversely, cytokinin inhibits this re-location [71] and the infection of root hair cell by rhizobia [77-80]. Consequently, it is tempting to speculate that plant hormones control plant-microbe interactions [81-86] by controlling the distribution of microdomains in the plasma membrane.

\section{Conclusions}

Plant microdomains play critical roles in plant development and plant-microbe interactions. The emergence of the FWL/CNR gene family as a new family of microdomain-associated genes and their role in regulating plant development and plant-microbe interactions would justify a stronger focus on characterizing the biological and biochemical functions of these genes and proteins. Specifically, knowing that numerous crop FWL/CNR genes are preferentially expressed in the plant root system (Figure 1), one potential field of investigation would be the characterization of the function of FWL/CNR genes and the microdomains in controlling the interaction between the root cells and the root microbiomes. We noticed that a diverse population of AtFWL/CNR genes were highly and more specifically expressed in epidermal root cells (e.g., AtFWL4, 6, 8, and 12 are expressed in both trichoblasts and atrichoblasts; Figure 2). These genes could play important roles in controlling the interaction between plant and soil microbes, similarly to GmFWL1, which is a major regulator of soybean nodulation.

From a functional point of view, there is also a need to characterize the regulatory mechanisms controlling the activity of the FWL/CND proteins. Post-translational modifications of microdomain-associated proteins control their subcellular localization and biological function. For instance, the S-acylation of the rice remorin RbREM1 [87], the Arabidopsis receptor like-kinase FLS2 [88], and the N-glycosylation of the RIM21 yeast protein [89] interfere with their localization in the microdomains. In more detail, after binding to its ligand, the Arabidopsis FLS2 protein is deacylated, leading to its re-localization and autophosphorylation. This active form of the FLS2 protein triggers downstream signaling to promote the plant innate immune response [88]. Hence, we assume that the reversibility of some post-translational modifications could also act as a major regulator of the localization, conformation, mobility, and function of the FWL/CNR proteins, allowing a rapid adaptive response to environmental stresses. For instance, post-translational modifications of the GmFWL1 protein could affect its interaction with other microdomain-associated proteins such as prohibitins. Hence, there is a clear need to better characterize the biochemical properties of the FWL/CND proteins to fully understand their role in plant cell biology.

Supplementary Materials: The following are available online at http://www.mdpi.com/2223-7747/9/3/377/s1, Table S1: Annotation and amino acid sequences of $134 \mathrm{FWL} / \mathrm{CNR}$ proteins identified across 13 different plant species.

Author Contributions: Conceptualization, S.T. and M.L.; Formal analysis, S.T., A.F., and M.L.; Original draft preparation, S.T. and M.L.; Writing-review and editing, S.T., A.F., and M.L.; Funding acquisition, M.L. All authors have read and agreed to the published version of the manuscript.

Funding: This research was funded by the National Science Foundation (grant numbers 1854326 and 1339194), and by the Nebraska Research Initiative core facility research grant. 
Conflicts of Interest: The authors declare no conflicts of interest.

\section{References}

1. Grosjean, K.; Mongrand, S.; Beney, L.; Simon-Plas, F.; Gerbeau-Pissot, P. Differential effect of plant lipids on membrane organization: Specificities of phytosphingolipids and phytosterols. J. Biol. Chem. 2015, 290, 5810-5825. [CrossRef] [PubMed]

2. Mongrand, S.; Stanislas, T.; Bayer, E.M.; Lherminier, J.; Simon-Plas, F. Membrane rafts in plant cells. Trends Plant Sci. 2010, 15, 656-663. [CrossRef] [PubMed]

3. Tapken, W.; Murphy, A.S. Membrane nanodomains in plants: Capturing form, function, and movement. J. Exp. Bot. 2015, 66, 1573-1586. [CrossRef] [PubMed]

4. Malinsky, J.; Opekarova, M.; Grossmann, G.; Tanner, W. Membrane Microdomains, Rafts, and Detergent-Resistant Membranes in Plants and Fungi. Annu. Rev. Plant Biol. 2013, 64, 501-529. [CrossRef] [PubMed]

5. Zhao, X.; Zhang, X.; Qu, Y.; Li, R.; Baluska, F.; Wan, Y. Mapping of Membrane Lipid Order in Root Apex Zones of Arabidopsis thaliana. Front. Plant Sci. 2015, 6, 1151. [CrossRef] [PubMed]

6. Krecek, P.; Skupa, P.; Libus, J.; Naramoto, S.; Tejos, R.; Friml, J.; Zazimalova, E. The PIN-FORMED (PIN) protein family of auxin transporters. Genome Biol. 2009, 10, 249. [CrossRef] [PubMed]

7. Teale, W.D.; Paponov, I.A.; Palme, K. Auxin in action: Signalling, transport and the control of plant growth and development. Nat. Rev. Mol. Cell Biol. 2006, 7, 847-859. [CrossRef]

8. Willemsen, V.; Friml, J.; Grebe, M.; van den Toorn, A.; Palme, K.; Scheres, B. Cell polarity and PIN protein positioning in Arabidopsis require sterol methyltransferase1 function. Plant Cell 2003, 15, 612-625. [CrossRef]

9. Luschnig, C.; Vert, G. The dynamics of plant plasma membrane proteins: PINs and beyond. Development 2014, 141, 2924-2938. [CrossRef]

10. Titapiwatanakun, B.; Blakeslee, J.J.; Bandyopadhyay, A.; Yang, H.; Mravec, J.; Sauer, M.; Cheng, Y.; Adamec, J.; Nagashima, A.; Geisler, M.; et al. ABCB19/PGP19 stabilises PIN1 in membrane microdomains in Arabidopsis. Plant J. 2009, 57, 27-44. [CrossRef]

11. Li, R.L.; Liu, P.; Wan, Y.L.; Chen, T.; Wang, Q.L.; Mettbach, U.; Baluska, F.; Samaj, J.; Fang, X.H.; Lucas, W.J.; et al. A Membrane Microdomain-Associated Protein, Arabidopsis Flot1, Is Involved in a Clathrin-Independent Endocytic Pathway and Is Required for Seedling Development. Plant Cell 2012, 24, 2105-2122. [CrossRef] [PubMed]

12. Liu, P.; Li, R.L.; Zhang, L.; Wang, Q.L.; Niehaus, K.; Baluska, F.; Samaj, J.; Lin, J.X. Lipid microdomain polarization is required for NADPH oxidase-dependent ROS signaling in Picea meyeri pollen tube tip growth. Plant J. 2009, 60, 303-313. [CrossRef] [PubMed]

13. Ovecka, M.; Berson, T.; Beck, M.; Derksen, J.; Samaj, J.; Baluska, F.; Lichtscheidl, I.K. Structural Sterols Are Involved in Both the Initiation and Tip Growth of Root Hairs in Arabidopsis thaliana. Plant Cell 2010, 22, 2999-3019. [CrossRef] [PubMed]

14. Cao, Y.; He, Q.; Qi, Z.; Zhang, Y.; Lu, L.; Xue, J.; Li, J.; Li, R. Dynamics and Endocytosis of Flot1 in Arabidopsis Require CPI1 Function. Int. J. Mol. Sci. 2020, 21, 1552. [CrossRef] [PubMed]

15. Fernandez-Calvino, L.; Faulkner, C.; Walshaw, J.; Saalbach, G.; Bayer, E.; Benitez-Alfonso, Y.; Maule, A. Arabidopsis plasmodesmal proteome. PLoS ONE 2011, 6, e18880. [CrossRef]

16. Grison, M.S.; Brocard, L.; Fouillen, L.; Nicolas, W.; Wewer, V.; Dormann, P.; Nacir, H.; Benitez-Alfonso, Y.; Claverol, S.; Germain, V.; et al. Specific Membrane Lipid Composition Is Important for Plasmodesmata Function in Arabidopsis. Plant Cell 2015, 27, 1228-1250. [CrossRef]

17. Kachroo, P.; Kachroo, A. Lipid-Modulated Trafficking in Plants. Mol. Plant 2020, 13, 351-353. [CrossRef]

18. Qiao, Z.; Libault, M. Function of plasma membrane microdomain-associated proteins during legume nodulation. Plant Signal. Behav. 2017, 12, e1365215. [CrossRef]

19. Eckardt, N.A. Membrane rafts and virus movement in plant cells. Plant Cell 2009, 21, 1326. [CrossRef]

20. Nathalie, L.-C.; Bouhidel, K. Plasma membrane protein trafficking in plant-microbe interactions: A plant cell point of view. Front. Plant Sci. 2014, 5, 735. [CrossRef]

21. Raffaele, S.; Bayer, E.; Lafarge, D.; Cluzet, S.; German Retana, S.; Boubekeur, T.; Leborgne-Castel, N.; Carde, J.P.; Lherminier, J.; Noirot, E.; et al. Remorin, a solanaceae protein resident in membrane rafts and plasmodesmata, impairs potato virus X movement. Plant Cell 2009, 21, 1541-1555. [CrossRef] [PubMed] 
22. Nagano, M.; Ishikawa, T.; Fujiwara, M.; Fukao, Y.; Kawano, Y.; Kawai-Yamada, M.; Shimamoto, K. Plasma Membrane Microdomains Are Essential for Rac1-RbohB/H-Mediated Immunity in Rice. Plant Cell 2016, 28, 1966-1983. [CrossRef]

23. Colou, J.; N'Guyen, G.Q.; Dubreu, O.; Fontaine, K.; Kwasiborski, A.; Bastide, F.; Manero, F.; Hamon, B.; Aligon, S.; Simoneau, P.; et al. Role of membrane compartment occupied by Can1 (MCC) and eisosome subdomains in plant pathogenicity of the necrotrophic fungus Alternaria brassicicola. BMC Microbiol. 2019, 19, 295. [CrossRef]

24. Rea, A.C. Lipid Rafts to the Rescue! Plants under Fungal Attack Recruit Phospholipase Ddelta. Plant Cell 2019, 31, 2819-2820. [CrossRef] [PubMed]

25. Haney, C.H.; Long, S.R. Plant flotillins are required for infection by nitrogen-fixing bacteria. Proc. Natl. Acad. Sci. USA 2010, 107, 478-483. [CrossRef] [PubMed]

26. Haney, C.H.; Riely, B.K.; Tricoli, D.M.; Cook, D.R.; Ehrhardt, D.W.; Long, S.R. Symbiotic rhizobia bacteria trigger a change in localization and dynamics of the Medicago truncatula receptor kinase LYK3. Plant Cell 2011, 23, 2774-2787. [CrossRef] [PubMed]

27. Abdallah, C.; Valot, B.; Guillier, C.; Mounier, A.; Balliau, T.; Zivy, M.; van Tuinen, D.; Renaut, J.; Wipf, D.; Dumas-Gaudot, E.; et al. The membrane proteome of Medicago truncatula roots displays qualitative and quantitative changes in response to arbuscular mycorrhizal symbiosis. J. Proteomics 2014, 108, 354-368. [CrossRef]

28. Lefebvre, B.; Timmers, T.; Mbengue, M.; Moreau, S.; Herve, C.; Toth, K.; Bittencourt-Silvestre, J.; Klaus, D.; Deslandes, L.; Godiard, L.; et al. A remorin protein interacts with symbiotic receptors and regulates bacterial infection. Proc. Natl. Acad. Sci. USA 2010, 107, 2343-2348. [CrossRef]

29. Liang, P.; Stratil, T.F.; Popp, C.; Marin, M.; Folgmann, J.; Mysore, K.S.; Wen, J.; Ott, T. Symbiotic root infections in Medicago truncatula require remorin-mediated receptor stabilization in membrane nanodomains. Proc. Natl. Acad. Sci. USA 2018, 115, 5289-5294. [CrossRef]

30. Son, S.; Oh, C.J.; Bae, J.H.; Lee, H.; An, C.S. GmREM1.1 and GmREM2.1, which encode the remorin proteins in soybean, have distinct roles during root nodule development. J. Plant Biol. 2015, 58, 17-25. [CrossRef]

31. Qiao, Z.; Brechenmacher, L.; Smith, B.; Strout, G.W.; Mangin, W.; Taylor, C.; Russell, S.D.; Stacey, G.; Libault, M. The GmFWL1 (FW2-2-like) nodulation gene encodes a plasma membrane microdomain-associated protein. Plant Cell Environ. 2017, 40, 1442-1455. [CrossRef]

32. Alpert, K.B.; Grandillo, S.; Tanksley, S.D. Fw-2.2-a Major Qtl Controlling Fruit Weight Is Common to Both Red-Fruited and Green-Fruited Tomato Species. Theor. Appl. Genet. 1995, 91, 994-1000. [CrossRef] [PubMed]

33. Chakrabarti, M.; Zhang, N.; Sauvage, C.; Munos, S.; Blanca, J.; Canizares, J.; Diez, M.J.; Schneider, R.; Mazourek, M.; McClead, J.; et al. A cytochrome P450 regulates a domestication trait in cultivated tomato. Proc. Natl. Acad. Sci. USA 2013, 110, 17125-17130. [CrossRef] [PubMed]

34. Frary, A.; Nesbitt, T.C.; Grandillo, S.; Knaap, E.; Cong, B.; Liu, J.; Meller, J.; Elber, R.; Alpert, K.B.; Tanksley, S.D. fw2.2: A quantitative trait locus key to the evolution of tomato fruit size. Science 2000, 289, 85-88. [CrossRef] [PubMed]

35. Mu, Q.; Huang, Z.J.; Chakrabarti, M.; Illa-Berenguer, E.; Liu, X.X.; Wang, Y.P.; Ramos, A.; van der Knaap, E. Fruit weight is controlled by Cell Size Regulator encoding a novel protein that is expressed in maturing tomato fruits. PLoS Genet. 2017, 13, e1006930. [CrossRef] [PubMed]

36. Libault, M.; Zhang, X.C.; Govindarajulu, M.; Qiu, J.; Ong, Y.T.; Brechenmacher, L.; Berg, R.H.; Hurley-Sommer, A.; Taylor, C.G.; Stacey, G. A member of the highly conserved FWL (tomato FW2.2-like) gene family is essential for soybean nodule organogenesis. Plant J. 2010, 62, 852-864. [CrossRef] [PubMed]

37. Li, Z.C.; He, C.Y. Physalis floridana Cell Number Regulator1 encodes a cell membrane-anchored modulator of cell cycle and negatively controls fruit size. J. Exp. Bot. 2015, 66, 257-270. [CrossRef]

38. Xu, J.; Xiong, W.; Cao, B.; Yan, T.; Luo, T.; Fan, T.; Luo, M. Molecular characterization and functional analysis of "fruit-weight 2.2-like" gene family in rice. Planta 2013, 238, 643-655. [CrossRef]

39. Alpert, K.B.; Tanksley, S.D. High-resolution mapping and isolation of a yeast artificial chromosome contig containing fw2.2: A major fruit weight quantitative trait locus in tomato. Proc. Natl. Acad. Sci. USA 1996, 93, 15503-15507. [CrossRef]

40. Cong, B.; Liu, J.P.; Tanksley, S.D. Natural alleles at a tomato fruit size quantitative trait locus differ by heterochronic regulatory mutations. Proc. Natl. Acad. Sci. USA 2002, 99, 13606-13611. [CrossRef] 
41. Shinozaki, Y.; Nicolas, P.; Fernandez-Pozo, N.; Ma, Q.; Evanich, D.J.; Shi, Y.; Xu, Y.; Zheng, Y.; Snyder, S.I.; Martin, L.B.B.; et al. High-resolution spatiotemporal transcriptome mapping of tomato fruit development and ripening. Nat. Commun. 2018, 9, 364. [CrossRef] [PubMed]

42. Goodstein, D.M.; Shu, S.; Howson, R.; Neupane, R.; Hayes, R.D.; Fazo, J.; Mitros, T.; Dirks, W.; Hellsten, U.; Putnam, N.; et al. Phytozome: A comparative platform for green plant genomics. Nucleic Acids Res. 2012, 40, D1178-D1186. [CrossRef]

43. Lamesch, P.; Berardini, T.Z.; Li, D.; Swarbreck, D.; Wilks, C.; Sasidharan, R.; Muller, R.; Dreher, K.; Alexander, D.L.; Garcia-Hernandez, M.; et al. The Arabidopsis Information Resource (TAIR): Improved gene annotation and new tools. Nucleic Acids Res. 2012, 40, D1202-D1210. [CrossRef] [PubMed]

44. Schmutz, J.; Cannon, S.B.; Schlueter, J.; Ma, J.; Mitros, T.; Nelson, W.; Hyten, D.L.; Song, Q.; Thelen, J.J.; Cheng, J.; et al. Genome sequence of the palaeopolyploid soybean. Nature 2010, 463, 178-183. [CrossRef]

45. Sato, S.; Nakamura, Y.; Kaneko, T.; Asamizu, E.; Kato, T.; Nakao, M.; Sasamoto, S.; Watanabe, A.; Ono, A.; Kawashima, K.; et al. Genome structure of the legume, Lotus japonicus. DNA Res. 2008, 15, 227-239. [CrossRef] [PubMed]

46. Young, N.D.; Debelle, F.; Oldroyd, G.E.D.; Geurts, R.; Cannon, S.B.; Udvardi, M.K.; Benedito, V.A.; Mayer, K.F.X.; Gouzy, J.; Schoof, H.; et al. The Medicago genome provides insight into the evolution of rhizobial symbioses. Nature 2011, 480, 520-524. [CrossRef] [PubMed]

47. Schmutz, J.; McClean, P.E.; Mamidi, S.; Wu, G.A.; Cannon, S.B.; Grimwood, J.; Jenkins, J.; Shu, S.; Song, Q.; Chavarro, C.; et al. A reference genome for common bean and genome-wide analysis of dual domestications. Nat. Genet. 2014, 46, 707-713. [CrossRef] [PubMed]

48. Jaillon, O.; Aury, J.M.; Noel, B.; Policriti, A.; Clepet, C.; Casagrande, A.; Choisne, N.; Aubourg, S.; Vitulo, N.; Jubin, C.; et al. The grapevine genome sequence suggests ancestral hexaploidization in major angiosperm phyla. Nature 2007, 449, 463-467. [CrossRef]

49. Sato, S.; Tabata, S.; Hirakawa, H.; Asamizu, E.; Shirasawa, K.; Isobe, S.; Kaneko, T.; Nakamura, Y.; Shibata, D.; Aoki, K.; et al. The tomato genome sequence provides insights into fleshy fruit evolution. Nature 2012, 485, 635-641. [CrossRef]

50. Tuskan, G.A.; Difazio, S.; Jansson, S.; Bohlmann, J.; Grigoriev, I.; Hellsten, U.; Putnam, N.; Ralph, S.; Rombauts, S.; Salamov, A.; et al. The genome of black cottonwood, Populus trichocarpa (Torr. \& Gray). Science 2006, 313, 1596-1604. [CrossRef]

51. Chan, A.P.; Crabtree, J.; Zhao, Q.; Lorenzi, H.; Orvis, J.; Puiu, D.; Melake-Berhan, A.; Jones, K.M.; Redman, J.; Chen, G.; et al. Draft genome sequence of the oilseed species Ricinus communis. Nat. Biotechnol. 2010, 28, 951-956. [CrossRef] [PubMed]

52. Ouyang, S.; Zhu, W.; Hamilton, J.; Lin, H.; Campbell, M.; Childs, K.; Thibaud-Nissen, F.; Malek, R.L.; Lee, Y.; Zheng, L.; et al. The TIGR Rice Genome Annotation Resource: Improvements and new features. Nucleic Acids Res. 2007, 35, D883-D887. [CrossRef] [PubMed]

53. Yu, J.; Hu, S.; Wang, J.; Wong, G.K.; Li, S.; Liu, B.; Deng, Y.; Dai, L.; Zhou, Y.; Zhang, X.; et al. A draft sequence of the rice genome (Oryza sativa L. ssp. indica). Science 2002, 296, 79-92. [CrossRef] [PubMed]

54. Schnable, P.S.; Ware, D.; Fulton, R.S.; Stein, J.C.; Wei, F.; Pasternak, S.; Liang, C.; Zhang, J.; Fulton, L.; Graves, T.A.; et al. The B73 maize genome: Complexity, diversity, and dynamics. Science 2009, 326, 1112-1115. [CrossRef]

55. International Brachypodium Initiative. Genome sequencing and analysis of the model grass Brachypodium distachyon. Nature 2010, 463, 763-768. [CrossRef]

56. Lang, D.; Ullrich, K.K.; Murat, F.; Fuchs, J.; Jenkins, J.; Haas, F.B.; Piednoel, M.; Gundlach, H.; Van Bel, M.; Meyberg, R.; et al. The Physcomitrella patens chromosome-scale assembly reveals moss genome structure and evolution. Plant J. 2018, 93, 515-533. [CrossRef]

57. Guo, M.; Rupe, M.A.; Dieter, J.A.; Zou, J.; Spielbauer, D.; Duncan, K.E.; Howard, R.J.; Hou, Z.; Simmons, C.R. Cell Number Regulator1 affects plant and organ size in maize: Implications for crop yield enhancement and heterosis. Plant Cell 2010, 22, 1057-1073. [CrossRef]

58. Guo, M.; Simmons, C.R. Cell number counts-the fw2.2 and CNR genes and implications for controlling plant fruit and organ size. Plant Sci. 2011, 181, 1-7. [CrossRef]

59. De Franceschi, P.; Stegmeir, T.; Cabrera, A.; van der Knaap, E.; Rosyara, U.R.; Sebolt, A.M.; Dondini, L.; Dirlewanger, E.; Quero-Garcia, J.; Campoy, J.A.; et al. Cell number regulator genes in Prunus provide candidate genes for the control of fruit size in sweet and sour cherry. Mol. Breed 2013, 32, 311-326. [CrossRef] 
60. Dahan, Y.; Rosenfeld, R.; Zadiranov, V.; Irihimovitch, V. A proposed conserved role for an avocado fw2.2-like gene as a negative regulator of fruit cell division. Planta 2010, 232, 663-676. [CrossRef]

61. Huerta-Cepas, J.; Serra, F.; Bork, P. ETE 3: Reconstruction, Analysis, and Visualization of Phylogenomic Data. Mol. Biol. Evol. 2016, 33, 1635-1638. [CrossRef] [PubMed]

62. Larkin, M.A.; Blackshields, G.; Brown, N.P.; Chenna, R.; McGettigan, P.A.; McWilliam, H.; Valentin, F.; Wallace, I.M.; Wilm, A.; Lopez, R.; et al. Clustal W and Clustal X version 2.0. Bioinformatics 2007, 23, 2947-2948. [CrossRef] [PubMed]

63. Price, M.N.; Dehal, P.S.; Arkin, A.P. FastTree: Computing large minimum evolution trees with profiles instead of a distance matrix. Mol. Biol. Evol. 2009, 26, 1641-1650. [CrossRef]

64. Mun, T.; Bachmann, A.; Gupta, V.; Stougaard, J.; Andersen, S.U. Lotus Base: An integrated information portal for the model legume Lotus japonicus. Sci. Rep. 2016, 6, 39447. [CrossRef] [PubMed]

65. Chen, T.; Ji, D.; Tian, S. Variable-angle epifluorescence microscopy characterizes protein dynamics in the vicinity of plasma membrane in plant cells. BMC Plant Biol. 2018, 18, 43. [CrossRef] [PubMed]

66. Denyer, T.; Ma, X.; Klesen, S.; Scacchi, E.; Nieselt, K.; Timmermans, M.C.P. Spatiotemporal Developmental Trajectories in the Arabidopsis Root Revealed Using High-Throughput Single-Cell RNA Sequencing. Dev. Cell 2019, 48, 840-852. [CrossRef]

67. Jean-Baptiste, K.; McFaline-Figueroa, J.L.; Alexandre, C.M.; Dorrity, M.W.; Saunders, L.; Bubb, K.L.; Trapnell, C.; Fields, S.; Queitsch, C.; Cuperus, J. Dynamics of gene expression in single root cells of A. thaliana. Plant Cell 2019, 31, 993-1011. [CrossRef]

68. Ryu, K.H.; Huang, L.; Kang, H.M.; Schiefelbein, J. Single-Cell RNA Sequencing Resolves Molecular Relationships among Individual Plant Cells. Plant Physiol. 2019, 179, 1444-1456. [CrossRef]

69. Shulse, C.N.; Cole, B.J.; Ciobanu, D.; Lin, J.; Yoshinaga, Y.; Gouran, M.; Turco, G.M.; Zhu, Y.; O’Malley, R.C.; Brady, S.M.; et al. High-Throughput Single-Cell Transcriptome Profiling of Plant Cell Types. Cell Rep. 2019, 27, 2241-2247. [CrossRef]

70. Zhang, T.Q.; Xu, Z.G.; Shang, G.D.; Wang, J.W. A Single-Cell RNA Sequencing Profiles the Developmental Landscape of Arabidopsis Root. Mol. Plant 2019, 12, 648-660. [CrossRef]

71. Qiao, Z.; Zogli, P.; Libault, M. Plant Hormones Differentially Control the Sub-Cellular Localization of Plasma Membrane Microdomains during the Early Stage of Soybean Nodulation. Genes 2019, 10, 1012. [CrossRef] [PubMed]

72. Breakspear, A.; Liu, C.; Roy, S.; Stacey, N.; Rogers, C.; Trick, M.; Morieri, G.; Mysore, K.S.; Wen, J.; Oldroyd, G.E.; et al. The root hair "infectome" of Medicago truncatula uncovers changes in cell cycle genes and reveals a requirement for auxin signaling in rhizobial infection. Plant Cell 2014, 26, 4680-4701. [CrossRef] [PubMed]

73. Nadzieja, M.; Kelly, S.; Stougaard, J.; Reid, D. Epidermal auxin biosynthesis facilitates rhizobial infection in Lotus japonicus. Plant J. 2018, 95, 101-111. [CrossRef] [PubMed]

74. van Spronsen, P.C.; Tak, T.; Rood, A.M.; van Brussel, A.A.; Kijne, J.W.; Boot, K.J. Salicylic acid inhibits indeterminate-type nodulation but not determinate-type nodulation. Mol. Plant Microbe 2003, 16, 83-91. [CrossRef] [PubMed]

75. Ferguson, B.J.; Mathesius, U. Phytohormone regulation of legume-rhizobia interactions. J. Chem. Ecol. 2014, 40, 770-790. [CrossRef] [PubMed]

76. Stacey, G.; McAlvin, C.B.; Kim, S.Y.; Olivares, J.; Soto, M.J. Effects of endogenous salicylic acid on nodulation in the model legumes Lotus japonicus and Medicago truncatula. Plant Physiol. 2006, 141, 1473-1481. [CrossRef]

77. Murray, J.D.; Karas, B.J.; Sato, S.; Tabata, S.; Amyot, L.; Szczyglowski, K. A cytokinin perception mutant colonized by Rhizobium in the absence of nodule organogenesis. Science 2007, 315, 101-104. [CrossRef]

78. Plet, J.; Wasson, A.; Ariel, F.; Le Signor, C.; Baker, D.; Mathesius, U.; Crespi, M.; Frugier, F. MtCRE1-dependent cytokinin signaling integrates bacterial and plant cues to coordinate symbiotic nodule organogenesis in Medicago truncatula. Plant J. 2011, 65, 622-633. [CrossRef]

79. Tirichine, L.; Sandal, N.; Madsen, L.H.; Radutoiu, S.; Albrektsen, A.S.; Sato, S.; Asamizu, E.; Tabata, S.; Stougaard, J. A gain-of-function mutation in a cytokinin receptor triggers spontaneous root nodule organogenesis. Science 2007, 315, 104-107. [CrossRef] 
80. Gonzalez-Rizzo, S.; Crespi, M.; Frugier, F. The Medicago truncatula CRE1 cytokinin receptor regulates lateral root development and early symbiotic interaction with Sinorhizobium meliloti. Plant Cell 2006, 18, 2680-2693. [CrossRef]

81. Deinum, E.E.; Geurts, R.; Bisseling, T.; Mulder, B.M. Modeling a cortical auxin maximum for nodulation: Different signatures of potential strategies. Front. Plant Sci. 2012, 3, 96. [CrossRef] [PubMed]

82. Paciorek, T.; Zazimalova, E.; Ruthardt, N.; Petrasek, J.; Stierhof, Y.D.; Kleine-Vehn, J.; Morris, D.A.; Emans, N.; Jurgens, G.; Geldner, N.; et al. Auxin inhibits endocytosis and promotes its own efflux from cells. Nature 2005, 435, 1251-1256. [CrossRef] [PubMed]

83. Rafiqi, M.; Ellis, J.G.; Ludowici, V.A.; Hardham, A.R.; Dodds, P.N. Challenges and progress towards understanding the role of effectors in plant-fungal interactions. Curr. Opin. Plant Biol. 2012, 15, 477-482. [CrossRef] [PubMed]

84. Turner, M.; Nizampatnam, N.R.; Baron, M.; Coppin, S.; Damodaran, S.; Adhikari, S.; Arunachalam, S.P.; Yu, O.; Subramanian, S. Ectopic expression of miR160 results in auxin hypersensitivity, cytokinin hyposensitivity, and inhibition of symbiotic nodule development in soybean. Plant Physiol. 2013, 162, 2042-2055. [CrossRef] [PubMed]

85. van Noorden, G.E.; Kerim, T.; Goffard, N.; Wiblin, R.; Pellerone, F.I.; Rolfe, B.G.; Mathesius, U. Overlap of proteome changes in Medicago truncatula in response to auxin and Sinorhizobium meliloti. Plant Physiol. 2007, 144, 1115-1131. [CrossRef]

86. Du, Y.; Tejos, R.; Beck, M.; Himschoot, E.; Li, H.; Robatzek, S.; Vanneste, S.; Friml, J. Salicylic acid interferes with clathrin-mediated endocytic protein trafficking. Proc. Natl. Acad. Sci. USA 2013, 110, 7946-7951. [CrossRef]

87. Fu, S.; Xu, Y.; Li, C.; Li, Y.; Wu, J.; Zhou, X. Rice Stripe Virus Interferes with S-acylation of Remorin and Induces Its Autophagic Degradation to Facilitate Virus Infection. Mol. Plant 2018, 11, 269-287. [CrossRef]

88. Chen, D.; Ahsan, N.; Thelen, J.; Stacey, G. S-Acylation of plant immune receptors mediates immune signaling in plasma membrane nanodomains. bioRxiv 2019, 720482. [CrossRef]

89. Obara, K.; Kotani, T.; Nakatogawa, H.; Kihara, A.; Kamura, T. N-glycosylation of Rim21 at an Unconventional Site Fine-tunes Its Behavior in the Plasma Membrane. Cell Struct. Funct. 2020, 45, 19021. [CrossRef] 